$1-1-1995$

\title{
2001: A Train Ride: A Guided Tour of the Sixth Amendment Right to Counsel
}

Gerald F. Uelmen

Santa Clara University School of Law, guelmen@scu.edu

Follow this and additional works at: http://digitalcommons.law.scu.edu/facpubs

\section{Recommended Citation}

58 Law \& Contemp. Probs. 13

This Article is brought to you for free and open access by the Faculty Scholarship at Santa Clara Law Digital Commons. It has been accepted for inclusion in Faculty Publications by an authorized administrator of Santa Clara Law Digital Commons. For more information, please contact sculawlibrarian@gmail.com. 


\title{
2001: A TRAIN RIDE: \\ A GUIDED TOUR OF THE SIXTH \\ AMENDMENT RIGHT TO COUNSEL
}

\author{
GERALD F. UELMEN*
}

In 1992, I conducted a tour of the history of the Fourth Amendment by bus, the form of transportation least favored by the current U.S. Supreme Court. ${ }^{1}$ When asked to put together a similar venture through the history of the Sixth Amendment right to counsel, I realized immediately that this was a trip that called for a train ride, for several reasons. First, for much of our history, our system of criminal justice for indigents strongly resembled a railroad. Second, one of the landmark cases arose from events surrounding a train ride. Finally, the ride is a trip through the southern United States, and my personal experience confirms that the best way to see the South is from the window of a train.

We start by selecting a locomotive. I picked out a Southern Pacific steam locomotive known, appropriately, as "Champion No. 1." We are going to board our train in Washington, D.C. in 1864. At each of our stops, we will add a new hero to our passenger list. But we begin our trip with a pair of heroes who are on their way back to Missouri with empty pockets. Their names are George W. Nabb and Luke Lawless. Back when they were young lawyers, in 1841, George and Luke were appointed by the federal circuit court for the territory of Missouri to represent a Native American from the Kickapoo tribe who was charged with murder, an offense punishable by death. They did a good job. After a three-day trial, their client was convicted of manslaughter. The attorneys then presented two bills for $\$ 500$ each to the Indian Bureau of the Department of Interior. After twenty-three years of frustrated attempts to collect, their claim was finally heard by the newly established United States Court of Claims. For authority, they cited the Sixth Amendment of the United States Constitution and an enactment of the First Congress in April 1790, before the Sixth Amendment was even ratified. The 1790 statute provided that any person charged with treason or any other capital offense

shall be allowed and admitted to make his full defense by counsel learned in the law; and the court before whom such person shall be tried, or some judge thereof, shall . . . immediately upon his request ... assign to such person such counsel, not exceeding

Copyright $\odot 1995$ by Law and Contemporary Problems

* Professor of Law, Santa Clara University.

1. Gerald F. Uelmen, 2001: A Bus Ride: A Guided Tour of the High Points and Low Points of Fourth Amendment Jurisprudence, CHAMPION, July 1992, at 7; see Florida v. Bostick, 501 U.S. 429 (1991). 
two, as such person shall desire, to whom such counsel shall have free access at all seasonable hours .... .

The Court of Claims concluded that while these provisions established a right to counsel, they did not establish any right of counsel to be paid. As the court put it, "[t]his is the declaration of a right in the accused, but not of any liability on the part of the United States."

That is the way it was, not only in the federal courts, but in the courts of most states as well, for the first century and a half of our national life. You will occasionally see this referred to as a glorious period of proud tradition for the bar. Do not believe it. The official reports are full of cases of lawyers trying to recover paltry sums for fees or expenses, and being told, in effect, to get by doing less for their clients. One of my favorites is an 1860 California Supreme Court opinion by Justice Steven Field, written before he was appointed to the U.S. Supreme Court by Abraham Lincoln. He declared:

[I]t is part of the general duty of counsel to render their professional services to persons accused of crime, who are destitute of means, upon appointment of the Court, when not inconsistent with their obligations to others; and for compensation, they must trust to the possible future ability of the parties. ... The duty imposed in this way may, it is true, be carried to unreasonable length, so as to become exceedingly burdensome; but we have heard no complaints of this character. It is usual . . . to apportion the duty among the different members of the profession practicing before it, so as to render it as light upon each as possible. ${ }^{4}$

I did not find it surprising that Justice Field heard no complaints, knowing of his imperious personality and subsequent history. In 1889 , he was accosted by former California Supreme Court Justice David Terry who was complaining about one of Field's rulings. Justice Field's bodyguard shot Terry dead. ${ }^{5}$

As the burden of providing indigent defense through uncompensated appointments grew, the quality of representation provided declined. There is a graphic description of the sad state of the Sixth Amendment right to counsel in 1917:

The classes of lawyers who are usually assigned to defend, present a phase of this question which cannot be regarded as unimportant. It is a regrettable fact that in nearly all communities (particularly in the larger cities) there is a type of lawyers who are not truly representative of a great profession. Their regard for the rights and liberties of their clients is measured solely from a commercial or financial standpoint. These are more persistent than any other lawyers in their search for clients. Too frequently their services, if rewarded by small fees, are half-hearted or openly negligible. This leaves their clients practically or wholly unprotected. They are commonly referred to as "shysters" but also described as "snitch lawyers," "jail

2. Act of April 30,1790, ch. 9, 1 Stat. 112, 118 (1790). With slight changes in phraseology, this provision still appears as 18 U.S.C. $\$ 3005$ (1988).

3. Nabb v. United States, 1 Ct. Cl. 173, 173 (1864).

4. Rowe v. Yuba County, 17 Cal. 61, $63-64$ (1860); $c f$. Lamont v. Solano County, 49 Cal. 158, 159 (1874) (refusing reimbursement to a lawyer who procured affidavits for his appointed client's defense, and advising the lawyer he is not required to incur such expenses but he "is simply to give his professional services").

5. See Albert R. Buchanan, David S. Terry of California, Dueling Judge (1956); see also In re Neagle, 135 U.S. 1 (1890). 
lawyers," "vampires," "legal vermin," "harpies," and by other inelegant but extremely emphatic phraseology. They are grasping and mercenary-without character, ability or conscience. They prey upon the ignorance or fear of the prisoner, or of his relatives or friends, in their effort to extort a fee. If it be not forthcoming (or often when it is) they advise the prisoner to plead guilty, on the pretext that he will get greater leniency from the court than by standing trial. He may at times go through the forms of a trial, but the defense is perfunctory on its face, and the client pays the penalty, perhaps not for the crime charged, but often for his poverty. ${ }^{6}$

It is now March of 1931, and our train is pulling into Chattanooga, Tennessee. Here we pass through one of the "hobo jungles," which over 200,000 homeless have established in the depths of the Depression. Many are called "Hoovervilles," in honor of our beloved President. We have picked up some uninvited passengers in Chattanooga, and a score of "hoboes" settle into open gondola cars as our train crosses the Alabama line into Jackson County, on its way to Memphis. Half of the hoboes are black, and half are white; a fight breaks out between them. The black boys succeed in throwing the white boys off the train, and the white boys straggle into a train station in Stevenson, Alabama to complain. The stationmaster calls Paint Rock, the next stop down the line, where a posse of deputies is assembled to search the train. The search turns up nine black boys, ranging in age from thirteen to twenty, one white boy, and two young white girls, Ruby Bates and Victoria Price.

Ruby and Victoria claim that they were raped by each of the black boys on the train. As muttering crowds gather, the militia is called in to guard the boys, who are transported to the jail adjoining the Scottsboro courthouse. Five days later, a grand jury returns an indictment charging all nine boys with rape, a capital offense. At their arraignment, no lawyer appears to defend them, so the judge announces he is appointing "all the members of the bar" for purposes of arraignment. ${ }^{8}$ All the members of the bar includes seven lawyers, three of whom were later retained to assist the prosecution. The only one the least bit interested in the piddling $\$ 100$ fee customarily paid to lawyers appointed in capital cases ${ }^{9}$ is Milo Moody, a 69-year-old courthouse denizen in the twilight of an unremarkable career. The case is set for trial one week later.

When the case is called for trial, the prosecution announces it wants to sever some of the defendants and proceed with four separate trials. Stephen R. Roddy, a lawyer from Chattanooga, appears in the courtroom and announces he was retained to assist the defendants, but he insists he will function only as an amicus, assisting local counsel. It is apparent to everyone that he is well

6. Mayer C. Golden, The Public Defender 18-20 (1917).

7. Most of the details of the Scottsboro case are taken from DAN T. CARTER, SCOTTSBORO: A TRAGEDY OF THE AMERICAN SOUTH (1969). See also QUENTIN REYNOLDS, COURTROOM 248-314 (1950).

8. Powell v. Alabama, 287 U.S. 45, 56 (1932).

9. The Alabama code provided for compensation of appointed attorneys in capital cases at a rate of not less than $\$ 50$ and not more than $\$ 100$. ALA. CODE tit. $15 \$ 318$ (1958). Court-appointed Alabama criminal defense attorneys are now compensated at a rate of $\$ 20$ per hour up to a maximum of $\$ 1,000$ for pretrial preparation and $\$ 40$ per hour for court time. ALA. CODE $\$ 15-12-21$ (1982 \& Supp. 1994). 
fortified with spirits. As one chronicler put it, his "modest legal abilities were further limited by his inability to remain sober." and says, "I will go ahead and help do anything I can."11 Thus, with no preparation, no investigation, and little consultation with their clients, Moody and Roddy proceed to trial representing all nine defendants.

The trials provide plenty of excitement for the crowds that jam the courtroom, with 2,000 more on the courthouse lawn. Ruby Bates and Victoria Price are subjected to very little cross-examination. The biggest surprise comes when one of the defendants testifies on cross-examination that the other eight boys all raped the girls, and that he, alone, was innocent. Moody and Roddy waive closing argument in all four trials, and the verdicts of guilty come in rapid succession, greeted by cheering crowds.

What is often overlooked about the first Scottsboro case is that it really was not a case about denial of counsel. It was a case about denial of competent counsel, that is, counsel who are prepared for trial.

After all nine boys were sentenced to death, the case took on a life of its own. A communist organization, the International Labor Defense (the "ILD"), struggled against the National Association for the Advancement of Colored People ("the NAACP") to control the defense, and the ILD won. At times, the ILD seemed more interested in pursuing propaganda than in pursuing justice. But it did retain some first-rate lawyers to pursue the appeals and retrials.

The first appeal went directly to the Alabama Supreme Court, providing an opportunity for the Attorney General of Alabama to really strut his stuff. His name was Thomas E. Knight, Jr., and his daddy, Thomas E. Knight, Sr., was a justice of the Alabama Supreme Court. For the defendants, a distinguished Chattanooga lawyer was employed to argue the denial of counsel issue. His name was George W. Chamlee. His grandfather was a decorated Confederate veteran, and Chamlee himself had served as district attorney for Chattanooga. He was one of the few lawyers in Tennessee who would defend Communists arrested for vagrancy for distributing leaflets. On one occasion, when a prosecutor expressed outrage that the defendants were seeking to overthrow the U.S. government, Chamlee quietly reminded the court that all their grandfathers had also repudiated the Federal Government and sworn allegiance to the Confederacy. ${ }^{12}$ The Alabama Supreme Court refused to view the Scottsboro case as a denial of counsel case. The principal opinion was authored by none other than Justice Thomas E. Knight, Sr., the Attorney General's daddy. ${ }^{13} \mathrm{He}$ noted that the defendants were represented throughout "by Hon. Milo Moody,

10. CARTER, supra note 7 , at 19.

11. Powell, 287 U.S. at 56.

12. CARTER, supra note 7 , at 55 .

13. 28 U.S.C. $\$ 455(\mathrm{~b})(5)$ (ii) (1988). Modern statutes and ethical standards require recusal where the judge's child appears as counsel. MODEL CODE OF JUDICIAL CONDUCT Canon 3E(1)(d)(ii) (1990). In 1967, U.S. Supreme Court Justice Tom C. Clark announced his retirement from the Court when his son, Ramsey Clark, was appointed as U.S. Attorney General. THE SUPREME COURT JUSTICES: ILLUSTRATED BIOGRAPHIES, 1789-1993, at 430 (Clare Cushman ed., 1993). 
an able member of the local bar of long and successful experience in the trial of criminal as well as civil cases." ${ }^{14}$ In defending the haste with which the trial was conducted, Justice Knight pointedly reminded his Yankee readers that the trial of McKinley's assassin Czolgosz in Buffalo, New York was conducted ten days after McKinley's death, and took only eight hours and twenty-six minutes. He then concluded:

True this Czolgosz verdict was rendered in a case where a human life had been taken in a most dastardly manner. But we are of the opinion that some things may happen to one worse than death, at the hands of an assassin, and, if the evidence is to be believed, one of those things happened to this defenseless woman, Victoria Price, on that ill-fated journey from Stevenson to Paint Rock, on March 25, 1931..$^{15}$

Chamlee did win a dissenting opinion from Alabama's chief justice on the right to counsel issue, though, which greatly strengthened the defense posture before the United States Supreme Court.

Six months later, the case was argued to the United States Supreme Court. The Court in 1931 reflected the deep conservatism of ten years of appointments dictated by Chief Justice William Howard Taft. Taft was gone now. In 1930, on the same day Taft announced his resignation, President Hoover nominated Charles Evans Hughes to replace him. The Scottsboro case was argued by Attorney General Thomas E. Knight, Jr., for the state, and Walter H. Pollak for the defense. George W. Chamlee was on the brief. The Court divided sevento-two in Powell v. Alabama, ${ }^{16}$ and Justice George Sutherland, a former senator from Utah who helped manage Warren Harding's presidential campaign, authored the majority opinion. Sutherland displayed a wonderful grasp of reality that was curiously absent in many of his other opinions, most of which have been consigned to oblivion. ${ }^{17} \mathrm{He}$ criticized the collective appointment of the entire bar as "little more than an expansive gesture," which would not give "that clear appreciation of responsibility or ... that individual sense of duty which would accompany the appointment of a selected member of the bar, specifically named and assigned." 18

Rather than focus on the trial, Justice Sutherland emphasized the denial of counsel prior to trial, to investigate and prepare the case. He stated:

[D]uring perhaps the most critical period of the proceedings against these defendants, that is to say, from the time of their arraignment until the beginning of their trial, when consultation, thorough going investigation and preparation were vitally important, the defendants did not have the aid of counsel in any real sense, although they were as much entitled to such aid during that period as at the trial itself. ${ }^{19}$

14. Powell v. State, 141 So. 201,213 (Ala. 1932).

15. Id. at 211.

16. 287 U.S. 45 (1932).

17. Sutherland's grasp of the reality of criminal trials came from personal experience. As a young lawyer in Utah, he served as counsel for the defense in capital cases. Whether Sutherland's opinions should remain in oblivion is a question addressed in H. ARKES, THE RETURN OF GEORGE SUTHERLAND (1994).

18. Powell, 287 U.S. at 56.

19. Id. at 57. 
The case was the first to hold that the constitutional guarantee of due process as to the states included a right to the assistance of counsel. Dissenting Justice Pierce Butler conceded the right, but insisted that the record showed no denial of the right. Noting that no application for a continuance was made, he concluded that the silence of Stephen Roddy and Milo Moody required a finding that the claim of lack of opportunity for preparation was groundless, "for if it had any merit they would be bound to support it."20

The Scottsboro case wound on for another eighteen years before the last Scottsboro defendant was released from prison in 1950. There were more heroes, like Samuel Leibowitz who argued the retrials. The case went back to the Supreme Court to establish the right to a jury from which blacks were not excluded. $^{21}$ But as we turn our train around and head for Charleston, the hero we should invite on board is George Chamlee of Chattanooga. He paid a heavy price for joining the Scottsboro defense, including having to face an ethics inquiry by the bar association on trumped-up charges designed to discredit the defense. And we should note that the difference between a pro forma defense and meaningful assistance of counsel will not emerge for judges whose reading of a cold record is not illuminated by the reality of experience.

There is one final footnote to the Scottsboro case. From 1931 until 1937, while the most celebrated case in Alabama history was splashed all over the front pages of every newspaper in the state, one might expect to read some comment about the case from the senior senator who represented Alabama in the United States Senate. That senator was Hugo Black. His discreet silence did not go unnoticed. ${ }^{22}$ In August of 1937, when President Franklin D. Roosevelt nominated Senator Hugo Black to be his first appointment to the United States Supreme Court, Norman Thomas of the Socialist Party asked the Senate Judiciary Committee to question Black about his silence on the Scottsboro case. The NAACP requested that he be questioned about his relationship to the Ku Klux Klan. ${ }^{23}$ Neither question was asked. After Black's confirmation, his prior membership in the Klan was exposed for the first time in a storm of public controversy.

Hugo Black came to the Supreme Court with a deep appreciation of the right to counsel, however. At the time of his election to the Senate, he was regarded as one of the most successful trial and appellate lawyers in the state of Alabama. His thriving law practice in Birmingham included both civil and criminal cases. One of his most sensational cases was the 1921 defense of a Methodist minister accused of killing a Catholic priest who had performed a marriage ceremony between the minister's daughter and a Puerto Rican. Black

20. Id. at 76 (Butler, J., dissenting).

21. Norris v. Alabama, 294 U.S. 587 (1935).

22. When four students from Vassar and Wellesley called upon Senator Black to protest, he asked them to make themselves "familiar with the facts concerning the trial and conviction of these negro rapers" before any further protest. NEWMAN, HUGO BLACK, A BIOGRAPHY 146 (1994).

23. Virginia Van Der Veer hamilton, Hugo Black, The Alabama Years 278 (1972). 
took full advantage of the prejudices of the jurors by bringing the groom to stand before the jury after closing the courtroom blinds to accentuate his dark complexion. In his closing argument, he emphasized his client's belief that the priest had married his daughter to a Negro, saying there were twenty mulattoes to every Negro in Puerto Rico. The jury acquitted the minister, to the outrage of the small Catholic community in Birmingham. ${ }^{24}$

Our train is now arriving in Charleston, South Carolina, and it is January of 1935. Two young marines, who were arrested for possessing and passing counterfeit twenty-dollar bills, have been indicted and are being arraigned. They plead not guilty. The judge asks the defendants if they have counsel. They reply "no." The court asks if they are ready for trial, and they respond "yes."

The cold record provides no corroboration of their claim that they asked the prosecutor if they could have a lawyer appointed, and he told them that in South Carolina courts did not appoint lawyers except for capital cases. The case proceeds to trial, and the two marines defend themselves as well as the average lay person usually does. The chief witness against them was not cross-examined, but they did voice an objection to his testimony on the ground that it was false. Here is how one defendant described his closing argument:

I told the jury, I don't consider myself a hoodlum as the District Attorney has made me out several times. I told the jury I was not a native of New York as the district attorney stated, but was from Mississippi and only stationed for government service in New York. I only said 15 or 20 words. I said I didn't think I was a hoodlum and could not have been one of very long standing because they didn't keep them in the Marine Corps. ${ }^{25}$

The jury returns a verdict of guilty, and both defendants are sentenced that same afternoon to four and one-half years in the federal penitentiary at Atlanta.

Eight months later, they file a petition for a writ of habeas corpus in federal district court in Atlanta. The court agrees that they were deprived of their Sixth Amendment right to counsel, but concludes that relief is not available by habeas corpus, since the error was not jurisdictional. ${ }^{26}$

At this point, the American Civil Liberties Union (the "ACLU") takes an interest in the case and asks a young Atlanta lawyer to take an appeal to the Fifth Circuit. That lawyer was Elbert Tuttle, who married a woman from Atlanta and moved there to practice law after graduating from Cornell Law School in 1923. Like George Chamlee, Elbert Tuttle occasionally defended Communists who passed out literature. He had taken one such case to the

24. It was later revealed that the police chief, the jury foreman, and the judge were all members of the Robert E. Lee Klan of the Ku Klux Klan, the same chapter that Hugo Black joined two years later. When Black's membership was exposed after his confirmation as a Supreme Court justice, he dismissed it as an act of political expediency in a masterful national radio address. Before he went on the radio, a national poll reported that $59 \%$ of Americans thought he should resign. After the address, only $44 \%$ thought so. Id. at 292,299 . Not until Clarence Thomas 54 years later would a Supreme Court justice come onto the Court with such a dark cloud over his head.

25. Johnson v. Zerbst, 304 U.S. 458, 461 (1938).

26. Bridwell v. Aderhold, 13 F. Supp. 253 (N.D. Ga. 1935). 
United States Supreme Court and won a five-to-four vindication of first amendment rights. ${ }^{27} \mathrm{He}$ did not fare as well with his right to counsel claim in the Fifth Circuit, though. The court concluded that the marines waived their Sixth Amendment rights by failing to assert them to the trial judge. The ACLU was ready to throw in the towel, but Elbert Tuttle insisted on seeking United States Supreme Court review at his own expense.

He arrived before the United States Supreme Court just as Justice Hugo Black did, and the six-to-two victory he won there was one of the first opinions authored by Justice Black. In Johnson v. Zerbst, ${ }^{28}$ Justice Black ruled that a waiver of the Sixth Amendment right to counsel cannot be presumed from a silent record, and that compliance with the constitutional mandate of the Sixth Amendment is a jurisdictional prerequisite to a federal court's authority to deprive an accused of his life or liberty. Justice Black conceived of defense counsel as an essential component of a court of justice. Here is how he put it:

A court's jurisdiction at the beginning of the trial may be lost "in the course of the proceedings" due to failure to complete the court-as the Sixth Amendment requires-by providing counsel for an accused who is unable to obtain counsel, who has not intelligently waived this constitutional guaranty, and whose life or liberty is at stake. $^{29}$

The same two dissenters in Powell v. Alabama, Justices Pierce Butler and James McReynolds, registered their disagreement with Black's sweeping opinion in Johnson v. Zerbst.

As our train moves on to Maryland, let us invite Elbert Tuttle aboard. His efforts in Johnson mark just the beginning of a heroic career that will span seventy years. In 1954, Tuttle was appointed to the Fifth Circuit, and he presided as its chief judge from 1960 to 1967. At the age of ninety-five, Tuttle held the distinction of having authored more published opinions than any other federal judge. In 1990, the building housing the Court of Appeals for the Eleventh Circuit in Atlanta was named the Elbert Parr Tuttle Court of Appeals Building. ${ }^{30}$

Johnson v. Zerbst did not transform the federal courts overnight into a sixth amendment paradise where every indigent defendant automatically got a lawyer. In the seven years after Johnson v. Zerbst, federal prisoners filed around 500 federal habeas petitions every year, and less than five percent of them were granted. ${ }^{31}$ The lower federal courts frequently held that a defendant who entered a guilty plea had no need of a lawyer, and thus a valid waiver of

27. Herndon v. Lowry, 301 U.S. 242 (1937).

28. 304 U.S. 458 (1938).

29. Id. at 468.

30. Dedication Ceremonies, 923 F.2d CXI-CXXX (1990).

31. David Fellman, The Constitutional Right to Counsel in Federal Courts, 30 NEB. L. REV. 559, 571-72 (1951). 
counsel could be presumed from the entry of a guilty plea. ${ }^{32}$ Not until the enactment of the Criminal Justice Act in 1964 was a federal system established to compensate appointed lawyers for their services.

Many states, however, were doing better than the federal courts in making counsel available to indigents. In 1942, thirty-five states had a clear legal requirement or an established practice to provide counsel on request in serious noncapital as well as capital cases. ${ }^{33}$ Maryland was not one of those states.

Smith Betts is a forty-three-year-old farmhand in Carroll County, Maryland. Carroll County is still quite rural, in the north central part of Maryland, snuggled against the Mason-Dixon line just south of Gettysburg, Pennsylvania. Betts was charged with robbery. He asked the court to appoint a lawyer because he could not afford one, and the court refused, explaining that in Maryland the court appointed lawyers for indigents only in rape and murder cases. Betts waived a jury trial, muddled through the cross-examination of the prosecution witnesses, and called a couple of alibi witnesses. He was then found guilty and sentenced to eight years in prison. To Justice Roberts of the United States Supreme Court, it was a simple case: "The simple issue was the veracity of the testimony for the State and that for the defendant." ${ }^{34}$ When Betts's petition for habeas corpus reached the Supreme Court, only three justices were ready to declare that due process required the appointment of counsel in all cases of serious crime. The majority, led by Justice Roberts, rejected a "hard and fast" rule, insisting that a denial of due process by a state court must be tested

by an appraisal of the totality of facts in a given case. That which may, in one setting, constitute a denial of fundamental fairness, shocking to the universal sense of justice, may, in other circumstances, and in the light of other considerations, fall short of such denial. ${ }^{35}$

As authority, he cited a coerced confession case from the same term applying a "totality of circumstances" analysis to the voluntariness of confessions. ${ }^{36}$ Owen Roberts had made his mark as a prosecutor in the Teapot Dome scandal before his appointment to the Court by President Hoover. He concluded his opinion with an argumentum ad horrendum: If we recognize the right to counsel for robberies, we will have to recognize it for traffic violations and ultimately for civil cases as well. ${ }^{37}$

In Betts v. Brady, Hugo Black emerges as a true champion of the right to counsel. But his trip from the Johnson v. Zerbst majority to the Betts v. Brady dissent was not a direct one. He detoured back to Alabama to write the

32. E.g., Macomber v. Hudspeth, 115 F.2d 114, 116 (10th Cir. 1940), cert. denied, 313 U.S. 558 (1941); Cooke v. Swope, 109 F.2d 955 (9th Cir. 1940). The Supreme Court ruled that a waiver of counsel could not be presumed from a guilty plea in Walker v. Johnston, 312 U.S. 275 (1941).

33. Betts v. Brady, 316 U.S. 455, 477 n.2 (1942) (Black, J., dissenting).

34. Id. at 472 (Roberts, J., opinion of the court).

35. Id. at 462 .

36. Lisenba v. California, 314 U.S. 219 (1942).

37. Betts, 316 U.S. at 473. 
unanimous opinion in Avery v. Alabama ${ }^{38}$ in 1940. Avery was arrested and charged with murder on a Monday, and the court appointed two local lawyers to represent him. The case was called for trial the following Thursday, and the lawyers asked for a continuance on the ground that their preoccupation with other cases precluded their preparation for trial. The motion was denied, and the defendant was promptly tried, convicted, and sentenced to death. Justice Black noted that in rural Alabama counties, lengthy preparation was unnecessary because everyone knew each other and everyone came to the county seat during the weeks the court was in session. ${ }^{39}$ The denial of continuances, he said, fell within the state's determination of local social policy. ${ }^{40}$ Avery was a rather typical example of the reluctance of federal courts to grant relief to defendants on the ground of incompetence of counsel. It further illuminates the tactical importance of Justice Sutherland's characterization of Scottsboro as a denial of counsel, rather than the case of incompetent counsel which it truly was.

Hugo Black's dissent in Betts v. Brady recognized where the "totality of the circumstances" test would lead the court. It would have to engage in a supervisory role, second-guessing the impact of denial of counsel with very little factual basis to inform its judgment. As he put it, "whether a man is innocent cannot be determined from a trial in which, as here, denial of counsel has made it impossible to conclude, with any satisfactory degree of certainty, that the defendant's case was adequately presented." 41 Justice Black will climb aboard as we point our train south for the twenty-one-year journey to full vindication of his view in Gideon v. Wainwright. During that period, the Supreme Court decided dozens of cases based on the totality of circumstances, weaving a bizarre web of irreconcilable precedents. Many of these cases were closely divided decisions, often with Justice Hugo Black dissenting. ${ }^{42}$

Finally, on January 8,1962, the Court received the handwritten petition of Clarence Earl Gideon that changed the course of sixth amendment history. The facts of Gideon's case were remarkably similar to the case of Smith Betts. Gideon was charged with the burglary of the Bay Harbor Poolroom in Panama City, Florida. When his case was called for trial, he asked to have a lawyer appointed to represent him. The court informed him that counsel could be appointed only for capital cases. Gideon then represented himself, and after a one-day jury trial, he was convicted and sentenced to five years in prison.

If the court had applied the "totality of circumstances" test of Betts v. Brady, it would have been hard put to conclude that a lawyer would have made much difference in Gideon's case. An eyewitness testified he saw Gideon come out

38. 308 U.S. 444 (1940).

39. Id. at 452 .

40. Id. at 447 .

41. Betts, 316 U.S. at 476 (Black, J., dissenting).

42. The cases are collected in Yale Kamisar, Betts v. Brady Twenty Years Later, 61 MiCH. L. REV. 219, 278-81 (1962). 
of the poolroom at 5:30 in the morning with bulging pockets and a pint of wine in his hand, go to a phone booth, and call a cab. The cigarette machine and jukebox in the poolroom had been broken open and the coins removed. Gideon himself called a cab driver to the stand, who confirmed that he had picked Gideon up at the scene of the burglary. He also called a friend who said she retrieved a partly full wine bottle at the telephone booth. ${ }^{43}$

We all know the wonderful story of how Abe Fortas was appointed to represent Gideon before the United States Supreme Court, and of the eloquent argument he presented. The opinion overruling Betts v. Brady was, of course, authored by Justice Hugo Black. It was not Justice Black's most memorable opinion. He found all the eloquence he needed in Justice Sutherland's opinion in Powell v. Alabama and his own opinion in Johnson v. Zerbst. He said, "In returning to these old precedents, sounder we believe than the new, we but restore constitutional principles established to achieve a fair system of justice." ${ }^{\prime 4}$ Noting that twenty-two states had filed an amicus brief urging that Betts was "an anachronism when handed down," Justice Black concluded with obvious satisfaction, "We agree." 45 The decision was unanimous. On March 18,1993 , we celebrated the thirtieth anniversary of this landmark decision.

To my mind, the real hero of Gideon was not Abe Fortas or Justice Hugo Black. It was a local lawyer named Fred Turner from Panama City, Florida. After Gideon's case was remanded to Florida for a retrial, Gideon fired the lawyer the ACLU had sent to represent him and asked the court to appoint Fred Turner, a local lawyer he had seen in action. Fred Turner accepted the appointment and spent a month investigating the case and preparing for trial. By coincidence, he had represented the chief prosecution witness in a previous case and knew the witness had a rather shady past. Turner's cross-examination managed to focus considerable suspicion on the complaining witness himself. He also managed to offer some innocent explanations for the most incriminating evidence against Gideon. His pocket full of coins was explained by a recent poker game. The final witness was Gideon himself, who asserted his innocence.

The jury was out one hour before they returned with a verdict of not guilty. ${ }^{46}$ In a case where a court following Betts $v$. Brady would conclude a lawyer could not have made a difference, Fred Turner proved how precarious such judgments really are. Fred Turner did make a difference-the difference between a verdict of guilty and a verdict of not guilty. Let us invite Fred Turner to board our train and continue south.

We are heading for Miami, and our trip of 100 miles will take us fifteen years. But during those fifteen years, the United States Supreme Court has undergone some remarkable changes. Of the nine justices who agreed in the historic reversal of Gideon's conviction, six were gone from the Court by 1975 .

43. ANTHONY LEWIS, GIDEON'S TRUMPET 57-62 (1966).

44. Gideon v. Wainwright, 372 U.S. 335,344 (1963).

45. Id. at 345 .

46. LEWIS, supra note 43 , at $226-37$. 
Chief Justice Earl Warren has been replaced by Chief Justice Warren Burger. Abe Fortas has already come and gone after replacing Justice Goldberg, and in turn being replaced by Justice Blackmun. Justice Powell has replaced Justice Harlan; Justice Stevens has replaced Justice Douglas; Justice Thurgood Marshall has replaced Justice Tom Clark; and Justice Hugo Black himself has been replaced by Justice William Rehnquist. There is one remarkably consistent pattern to all these appointments. With one exception, Justice Thurgood Marshall, none of them had ever represented a defendant in a criminal case. Of those who decided Gideon, only Justices Brennan, Stewart, and White were still on the Court when it finally addressed the standard of competence to be demanded from appointed counsel representing indigent criminal defendants. The case that presents this issue for resolution is the case of David Leroy Washington.

David Leroy Washington celebrated the 1976 bicentennial with a ten-day crime spree that included three brutal murders. His victims included a Protestant minister, an elderly woman, and a twenty-year-old college student. After he was arrested and confessed to the third murder, an experienced criminal defense attorney was appointed to represent him. Ignoring the advice of that attorney, Washington then confessed to the first two murders and pleaded guilty to all three murders. The judge accepting the plea said he had "a great deal of respect for people who are willing to step forward and admit their responsibility." 47 Washington then agreed to waive his right to have a sentencing jury, and the judge respectfully sentenced him to death on all three counts of first-degree murder. One would think that this was not the kind of case where a zealous advocate could have made much difference.

Not until Washington got a different lawyer and filed a federal writ of habeas corpus did it emerge that his first lawyer had pretty much given up on David Leroy Washington after he ignored his advice and confessed to the first two murders. No presentence report was even requested. No effort was made to find or present any character witnesses or psychiatric experts. Fourteen affidavits and two psychiatric reports suggested that lots of evidence was available to show that Washington was chronically depressed because of his inability to support his wife and children. To rebut this evidence, the State called the sentencing judge, who testified that none of this evidence would have altered his conclusion that Washington deserved the death penalty.

The brand new Court of Appeals for the Eleventh Circuit in Atlanta granted an en banc hearing of Washington's case and formulated some very specific guidelines to define counsel's duty to investigate. The court also ruled that if a defendant shows that counsel's failings worked to his actual and substantial disadvantage, the writ must be granted unless the state proves counsel's effectiveness was harmless beyond a reasonable doubt. ${ }^{48}$ The United States

47. Washington v. Strickland, 693 F.2d 1243, 1247 (former 5th Cir. 1982).

48. Id. 
Supreme Court then granted certiorari, using the case to resolve a conflict among the circuits as to the appropriate standards for habeas challenges based on effectiveness of counsel.

Weighing in with the prosecution to urge reversal of the Eleventh Circuit standards were the Solicitor General of the United States and the attorneys general of forty-one states. Delivering the opinion for a majority of seven Justices was President Ronald Reagan's first appointment to the Court, Justice Sandra Day O'Connor, who was appointed when Justice Potter Stewart retired in 1981. The Court reversed the Eleventh Circuit and ruled instead that only a broad standard of reasonableness should be applied. Counsel's performance must be so deficient, O'Connor said, that counsel was not functioning as the "counsel" guaranteed by the Sixth Amendment. The purpose of the Sixth Amendment, according to Justice O'Connor, was not to improve the quality of legal representation, but "simply to ensure that criminal defendants receive a fair trial." ${ }^{\prime 49}$ Even if counsel's performance falls below this standard, the Court concluded, the defendant must show a reasonable probability that but for counsel's ineptitude, the result would have been different. ${ }^{50}$

The standards established in Strickland sound suspiciously like a resurrection of the totality of circumstances test of Betts v. Brady, given a "respectful burial" by Justice Harlan in Gideon $v$. Wainwright. ${ }^{51}$ But the only one who seemed to notice was dissenting Justice Thurgood Marshall. Perhaps that is because he was the only one left on the Court who had ever represented a criminal defendant. He found the broad standard of "reasonableness" of little use:

In essence, the majority has instructed judges called upon to assess claims of ineffective assistance of counsel to advert to their own intuitions regarding what constitutes "professional" representation, and has discouraged them from trying to develop more detailed standards governing the performance of defense counsel. ${ }^{52}$

With respect to the standard of prejudice, Justice Marshall presented an argument which echoed the point made by Hugo Black in his Betts v. Brady dissent forty years earlier:

It is often very difficult to tell whether a defendant convicted after a trial in which he was ineffectively represented would have fared better if his lawyer had been competent. Seemingly impregnable cases can sometimes be dismantled by good defense counsel. On the basis of a cold record, it may be impossible for a reviewing court confidently to ascertain how the government's evidence and arguments would have stood up against rebuttal and cross-examination by a shrewd, well-prepared lawyer. ${ }^{53}$

Marshall's point, of course, was the principal lesson of Gideon v. Wainwright. In twenty short years, that lesson had been forgotten, and the ad hoc inconsis-

49. Strickland v. Washington, 466 U.S. 668,689 (1984).

50. Id. at 694.

51. 372 U.S. 335 (Harlan, J., concurring). Betts v. Brady enjoyed another resurrection in Gagnon v. Scarpelli, 411 U.S. 778, 788 (1973), suggesting that rather than a "respectful burial," Betts v. Brady needs a wooden stake through the heart.

52. Strickland, 466 U.S. at 708 (Marshall, J., dissenting).

53. Id. at 710 . 
tency of Betts v. Brady was again triumphant. The Strickland opinion was delivered on May 14, 1984. Two months later, on July 13, 1984, David Leroy Washington was strapped into Florida's electric chair and executed.

The hero who should climb on board our train as we head back to Washington is Thurgood Marshall. While Marshall is mainly remembered for his work in dismantling school segregation, he was a criminal defense lawyer of some note before his appointment to the Supreme Court. In dozens of cases, he represented black defendants on trial for their lives. In many of these cases, he entered the case on habeas or appeal after trial counsel had already botched the case. ${ }^{54}$ Justice Marshall's experience had taught him an unforgettable lesson: that there was a direct relationship between the black population on southern death rows and the quality of counsel appointed to represent indigent defendants.

On October 12, 1984, three months after David Leroy Washington was executed in Florida, President Ronald Reagan signed the Comprehensive Crime Control Act of $1984 .^{55}$ Presidential election years have become noted for quadrennial "tough on crime" measures, but the 1984 law contained an unnoticed clause that would be put to use to get tough with criminal defense lawyers. In strengthening the forfeiture laws used to seize the assets of drug dealers, the law created a legal fiction that made the government's property interest in the proceeds of illegal activity relate back to the time of the illegal activity. ${ }^{56}$ It allowed the government to recover assets even from third parties to whom they were transferred prior to the time the defendant's conviction rendered them forfeitable. There is little evidence that Congress ever even thought about the impact this provision would have on attorneys' fees, but it did not take the Reagan Administration long to think about it. In a number of major drug cases around the country, the Justice Department notified lawyers that the fees they were being paid by their clients were subject to forfeiture. ${ }^{57}$

One of those cases was the prosecution of Christopher Reckmeyer in the Eastern District of Virginia. Reckmeyer was at the hub of a marijuana and hashish distribution ring for ten years. His attorneys negotiated a plea bargain in which Reckmeyer forfeited assets worth over one million dollars and received a prison sentence of seventeen years. ${ }^{58}$

After the defendant was sentenced and the forfeiture of the assets ordered, the law firm of Caplin \& Drysdale, the lawyers who represented Reckmeyer throughout the grand jury investigation and the plea negotiations, sought to recover a total of $\$ 195,000$ in legal fees, including a $\$ 25,000$ retainer placed in

54. See Gerald F. Uelmen, Justice Thurgood Marshall and the Death Penalty: A Former Criminal Defense Lawyer on the Supreme Court, 26 ARIZ. STATE L.J. 403 (1994).

55. Pub. L. No. 98-473, 98 Stat. 1837 (1984).

56. 18 U.S.C. § 1963(c) (1984); 21 U.S.C. \$ 853(c) (1984).

57. See Kathleen F. Brickey, Attorney's Fee Forfeitures: on Defining "What" and "When" and Distinguishing "Ought" from "Is," 36 EMORY L.J. 761 (1987).

58. United States v. Reckmeyer, 786 F.2d 1216 (4th Cir. 1986). 
a trust account. The trial court granted their claim, but the Fourth Circuit, hearing the case en banc, reversed. The case arrives at the United States Supreme Court at the same time our train arrives in Union Station, in the spring of 1989.

President Ronald Reagan has completed his transformation of the United States Supreme Court and gone back to California. In 1986, he appointed William Rehnquist as Chief Justice, to replace Warren Burger, and named Justice Antonin Scalia to fill Rehnquist's seat. In 1987, Justice Anthony Kennedy was named to replace Justice Powell, after the failure of the nomination of Robert Bork. Thus, only Justices Brennan and White remained from the Court that decided Gideon v. Wainwright in 1963. Justice White wrote the majority opinion in Caplin \& Drysdale v. United States. ${ }^{59}$ It was a five-tofour opinion, and it gave short shrift to the argument that the forfeiture of attorneys' fees was a violation of Sixth Amendment rights. He quoted the Court of Appeals opinion:

The modern day Jean Valjean must be satisfied with appointed counsel. Yet the drug merchant claims that his possession of huge sums of money ... entitles him to something more. We reject this contention, and any notion of a constitutional right to use the proceeds of crime to finance an expensive defense. ${ }^{60}$

In his dissent, joined by Justices Brennan, Marshall, and Stevens, Justice Harry Blackmun noted the unanimity of district court judges in recognizing the claims of lawyers to recovery of their fees from forfeited assets. He attributed it to their better understanding of the consequences of the majority ruling for the adversary system. "Had it been Congress' express aim to undermine the adversary system as we know it," he exclaimed, "it could hardly have found a better engine of destruction than attorneys'-fee forfeiture."

Justice Harry Blackmun's greatest strength was his grasp of the systemic consequences of a ruling, and he had a keen appreciation of the role that retained counsel play in our adversary system. In that respect, he saw Gideon and Strickland as establishing only a minimum standard. The "outer limits" of the right to counsel, he insisted, were in the right to counsel of choice, "the primary, preferred component of the basic right' protected by the Sixth Amendment." 62 He foresaw an exodus of talented lawyers from criminal defense work, as the standardization and socialization of the appointed counsel system is beggared by a government that devotes vastly more of its resources to prosecution than to defense. From his perspective, the payment of forfeited assets to defense attorneys was not a diversion of government resources; it was an investment in a healthy adversary system. As he put it,

[t]here is a place in our system of criminal justice for the maverick and the risk-taker and for approaches that might not fit into the structured environment of a public

59. 491 U.S. 617 (1989).

60. Id. at 630 .

61. Id. at 648 (Blackmun, J., dissenting).

62. Id. at 645 (quoting United States v. Harvey, 814 F.2d 904, 923 (4th Cir. 1987)). 
defender's office, or that might displease a judge whose preference for noncon-

frontational styles of advocacy might influence the judge's appointment decisions. ${ }^{63}$

Our train is stuck in Washington, but we should nonetheless invite Justice Harry Blackmun aboard to join our galaxy of sixth amendment heroes. His troubled vision of the future of the right to counsel was certainly prophetic. In the first two years after 1989, the number of criminal defendants represented in the federal courts by court-appointed lawyers or public defenders increased 12.4 percent. ${ }^{64}$ Each year, the funding available to pay appointed lawyers runs out earlier, and the government looks for new ways to tighten the purse strings. ${ }^{65}$ Each year, as defense lawyers and the organizations that represent them go hat in hand to the government, the independence of the criminal defense bar is further compromised.

On March 18, 1993, the New York Times published an editorial marking the thirtieth anniversary of the Gideon decision. ${ }^{66}$ The author noted that after three decades, the United States is far from delivering on the promise of Gideon:

In courts across the land, judges must beg the private bar to step up and take on criminal cases for which many lawyers are poorly equipped and grossly undercompensated. Public defender systems are soft targets for budget cutters, state and federal. Congress, which must pay for counsel appointed in the federal courts, is perennially guilty of late and inadequate funding. ${ }^{6}$

As we size up the future prospects of getting our right to counsel train rolling again, we should reflect on some of the lessons our galaxy of heroes has taught us. George Nabb and Luke Lawless, whose twenty-three-year quest for reasonable compensation left them with empty pockets, taught us that the defense of criminals will never have a very high funding priority with any governmental entity. The experience of George Chamlee in the Scottsboro case suggests that the difference between a denial of counsel altogether and the provision of incompetent or unprepared counsel is an elusive one, and the gulf that the law has created between the two is largely a fiction. Elbert Tuttle's victory in Johnson v. Zerbst offers a revolutionary concept that is frequently overlooked-that a tribunal cannot even call itself a court of justice until it is completed by the presence of counsel for the accused. If courts regarded the competence of defense counsel as just as essential to the achievement of justice as the competence of the judge, we would certainly see a different standard of competence applied. Justice Hugo Black's consistent lesson was that the process of reviewing the record to ascertain whether lack of competent counsel was prejudicial is an adventure in folly. We will never know what difference a

63. Id. at 647 .

64. REPORT OF THE COMMTTEE TO REVIEW THE CRIMINAL JUSTICE ACT, reprinted in 52 Crim. L. Rep. (BNA) 2265, 2278 (Mar. 10, 1993).

65. AdMINISTRATIVE OFFICE OF THE U.S. COURTS, FEDERAL DefENDER SERVICES: A STATUS REPORT 2 (August 1993).

66. Gideon's Promise, Still Unkept, N.Y. TIMES, Mar. 18, 1993, at A22.

67. Id. 
competent lawyer could have made until we have a competent lawyer try the case. Fred Turner of Panama City offered a convincing demonstration of that proposition in representing Clarence Earl Gideon at his retrial. Justice Thurgood Marshall seemed to be the only one who did not forget that lesson in Strickland v. Washington, perhaps because he was the only one left on the court who had ever been a criminal defense lawyer. That is a perspective that has now totally disappeared from the Court for the first time in its history. And Justice Harry Blackmun has given us a systemic perspective that sounds a grave alarm for the disappearance of an independent criminal defense bar that does not depend upon the largesse of its adversary for its health.

Even though our travels have been confined to the American South, we should not conclude that the unmet challenge of Gideon is confined to the South. Nor should it surprise us that, with rare exception, our galaxy of heroes is very much of the South, including a Supreme Court justice who was nearly unseated because of his prior membership in the Ku Klux Klan.

Let me finish with the concluding words of the New York Times editorial observing the thirtieth anniversary of Gideon. Noting the signs of hope that the Clinton Administration will take the Sixth Amendment seriously, the Times concluded,

Gideon's is a checkered history, a continuing struggle between constitutional ideal and performance. But hope for better performance rests on more than idealism. It rests on the unassailable truth that without a lawyer for the defense-a trained advocate the accused can trust-trials have no legitimacy. A government that stages mock trials mocks the whole notion of just government. Aware citizens won't tolerate such injustice. ${ }^{68}$

68. Id. 
HeinOnline -- 58 Law \& Contemp. Probs. 301995 